Pak. j. sci. ind. res. Ser. B: biol. sci. 2016 59(1) 33-37

\title{
Effect of Different Combinations of Gums and Emulsifiers on the Quality of Bread
}

\author{
Muhammad Rizwan Haider ${ }^{\mathrm{a}}$, Ghulam Mueen ud dinª, Muhammad Abrar ${ }^{\mathrm{b}}$, \\ Arshad Mehmood ${ }^{\mathrm{a}}$, Ashiq Hussain ${ }^{\mathrm{a} *}$ and Muhammad Umar Nasir ${ }^{\mathrm{a}}$ \\ ${ }^{a}$ Institute of Food Science and Nutrition, University of Sargodha, Sargodha, Pakistan \\ ${ }^{\mathrm{b}}$ Ayub Agriculture Research Institute, Faisalabad, Pakistan
}

(received December 8, 2014; revised August 31, 2015; accepted September 21, 2015)

\begin{abstract}
A project was designed to evaluate the effect of different combinations of emulsifiers and gums on the quality of bread. Wheat variety AARI-11 was milled to get straight grade flour and mixed with the Emulsifiers (DMG \& DATEM) and Gums (G.G \& CMC) in a quantity of (0.3- 0.6 \%). Both, straight grade flour as well as treated flour (combination with gums and emulsifiers) were subjected to proximate and rheological analysis. Results of the rheological study showed a significant change in water absorption, dough development time, dough stability time and dough viscosity i.e. W/A 61.33-62.93\%, D.D.T 3.9$4.8 \mathrm{~min}$, D.S.T 7-9.1 min and 818.33-950.00 BU, respectively. Breads prepared with both flours were also studied for their sensory attributes during storage after the interval of $24 \mathrm{~h}$. The highest score was awarded to $\mathrm{T}_{1}(0.3 \%$ DATEM \& $0.5 \%$ guar gum) on the bases of its excellent external attributes (colour of crust, volume, symmetry of form, evenness of bake and crust character) and internal characteristics (aroma, grain, texture, taste, mastication and colour of crumb). After the sensory and physicochemical analyses, it is concluded that with the addition of DATEM $(0.3 \%)$ and guar gum $(0.5 \%)$ resulted in good quality of bread.
\end{abstract}

Keywords: bakery product, straight grade flour, rheological study, water absorption

\section{Introduction}

Bread is an important food product and largely consumed all over the world. It is a bakery product having good aroma, texture and taste. It is prepared by baking of dough and having common ingredients like salt, fat, water and yeast. There are also some optional ingredients like egg, sugar, spice, milk, vegetables, nuts and seeds. Bread is leavened by yeast through the fermentation of wheat flour sugars that derives from starches. The leavening property is due to the elastic structure of gluten that has the ability to strengthen and change itself. So, it helps the shaping of bread in bread making process by gas retention. The different characteristics i.e., softness, crust, flavour, sizes, texture, shapes and eating qualities of bread explain that wether it is good quality or bad quality type of bread (Cauvain, 1994).

Bread comes in the categories of perishable food products having very short shelf life and usually consumed around 4-5 days of manufacturing. Ropiness and mouldiness are the major factors responsible for the deterioration and spoilage of the bread. But there are some additives which are added in bread to enhance the storage duration and bread quality. Generally, the

*Author for correspondence; E-mail: aphdft@yahoo.com fresh baked bread have attractive colour, rubbery and soft crumb texture, a pleasant smell, fine slicing characteristics and the mouth watering feel (Bakke and Vickers, 2007).

According to market demand of bread, different problems related to bread preservation may occur during storage. To overcome these problems, various techniques and different additives are used to enhance the quality of bread and baked products. There are some additives which are mostly being used nowadays in bakery industries for the good quality of baked goods. Hydrocolloids and emulsifiers are major two types of substances which are mostly used in baking units. The emulsifiers consisted of both lipophilic and hydrophilic properties hence, it provides a chance to react at water-oil inter phase. Thus by growing emulsion capabilities, the amphiphilic part takes part to produce the complex structure with protein and starch (Stampfli and Nersten, 1995).

In general, the characteristics of emulsifiers in the bakery industry are to improve the dough strength, crumb structure, water absorption rate, brighter crumb and finer grains. Emulsions reduce the crust thickness, enhance the slicing properties of bread and improve gas retention during fermentation (Selomulyo and Zhou, 2007; Stampfli and Nesstin 1995). 
Practically it was supposed that additives delay in fixing the structure of crumb, which is correlated with staling (Azizi and Rao, 2005). There is another group of additives which is used to enhance the quality of bread and known as hydrocolloids or gums. These are polysaccharides which are extracted from seaweeds, plants, microbial sources and from modified biopolymers through the chemical treatment of cellulose, as well as derived from plants exudates. Commonly used hydrocolloids in the industry are alginates, guar gum, carrageenans, arabic gum, carboxymethyl cellulose and agar (Gomez-Diaz and Navaza, 2003).

Hydrocolloids are also known as water-soluble gums and have been found specifically a wide range of functions i.e., thickening, gelatinization, gel formation, fragmentation, melting, foam stabilization, retro gradation of starch and increasing water-holding capacity. Hydrocolloids may be used alone or in combination to achieve their functional characteristics. When these are used in little amount i.e., $<1 \%(\mathrm{w} / \mathrm{w})$ in flour, then there is chance to increase in water retention and ultimately decrease in the firmness of crumb. Hydrocolloids have hydrophilic nature so prevent ice crystals growth during frozen storage and water migration to coating, so it increases thaw stability. Hydrocolloids have unbiased aroma and taste which allows a free flavour liberate of all recipe components. They provide an oily body to products having reduced fat, in which texturizing properties and water-binding ability compensate for the little fat contents. These compounds have been used in gluten formulation as substitutes of gluten. Additives are used in bakery to help processing, guarantee constant quality and balance for dissimilarity in raw materials and to preserve food properties and freshness (Ribotta et al., 2008).

In general, the addition of emulsifiers and hydrocolloids enhance the value as improvers of bakery products. These are broadly used in baked products to increase overall fresh product's quality, dough handling properties and to extend shelf-life of stored goods. Present study was conducted to determine the effect of different combinations of gums and emulsifiers on the quality of bread.

\section{Materials and Methods}

The research was carried out to study the effect of different combinations of gums and emulsifiers on the quality of bread. The work was conducted at Institute of Food Science and Nutrition, University of Sargodha,
Sargodha and in a local baker in Lahore, Pakistan. Details of raw materials used and the procedures employed are as follow:

Procurement of raw materials. Wheat variety (AARI11) was procured from Wheat Research Institute, Ayub Agricultural Research Institute (AARI) Faisalabad, Pakistan. Hydrocolloids (guar gum, carboxymethyl cellulose) and emulsifiers DATEM (Diacetile tartaric acid of mono glycerides), DMG (dimono glyceride) were purchased from Sakhawat Essence (Lahore, Pakistan).

Physical characteristics of wheat grains. The raw materials were cleaned manually to remove dirt, dust, damaged seeds, seeds of other crops and other foreign matters. Wheat variety (AARI-11) was tested for different physical characteristics like thousand kernel weight by the method No. 84-10 as described in AACC (2000). Three replicates of each measurement were made. Straight grade flour was prepared according to method No.26-95 (AACC, 2000).

Physicochemical analysis. Moisture content, ash, protein, crude fat, crude fibre content in samples was determined according to the procedure described in AACC (2000). Nitrogen free extract (NFE) was calculated by subtracting the percentages of moisture, ash, crude protein, fat and crude fibre from 100 as per the following formula:

$$
\begin{aligned}
& \text { NFE }(\%)=100-(\text { moisture } \%+\text { crude protein } \% \\
& + \text { crude fat } \%+\text { crude fibre } \%+\text { ash } \%)
\end{aligned}
$$

Rheological studies of acceptable straight grade wheat flour and farinograph. The rheological behaviour of the treated flour samples was evaluated by using Brabender Farinograph (Model: Brabender DUISBURG 380 , Germany) according to method described in AACC method no. 54-21 (AACC, 2000). Dough properties such as water absorption, dough development time and dough stability were interpreted by the Farinogram.

$\alpha$-Amylase activity. Falling numbers were determined using Pertin Falling Number Apparatus 1900 (Pertin Instruments AB, SE 1405, Huddige, Sweden) according to the method No.56-81 as described in AACC (2000).

Experimental design. Various treatments of straight grade flour were made to study the effect of different combinations of gums and emulsifiers on the quality of bread. This treated flour contain gums and emulsifiers in different proportion as shown in Table 1. 
Formulation of bread. The breads with each treatment were prepared in a local bakery in Lahore, Pakistan. The basic bread recipe contained flour $(5 \mathrm{~kg})$, salt (100 g), yeast (100 g), shortening (50 g), calcium acetate (4 g), calcium propionate (400 g), sugar (400 g) and baking improver (0.5\%). Emulsifier (MDG and DATEM) and gums (guar gum and CMC) were added according to the experimental design shown in Table 1. The water added in each formulation was based on farinograph water absorption (Table 1). Dough was mixed in a spiral mixer for $3 \mathrm{~min}$ at $90 \mathrm{rpm}$, then for $7 \mathrm{~min}$ at $120 \mathrm{rpm}$. After resting for $10 \mathrm{~min}$, it was divided into $70 \mathrm{~g}$ pieces and rounded. Dough was proofed at $32{ }^{\circ} \mathrm{C}$ and $80 \%$ relative humidity for $75 \mathrm{~min}$, baked at $230{ }^{\circ} \mathrm{C}$ for $2 \mathrm{~min}$ with $0.2 \mathrm{~L}$ of steam, and finally baked at $170{ }^{\circ} \mathrm{C}$ for $10 \mathrm{~min}$. Breads were packaged in polyethylene bags. Physical and sensory analyses were carried out.

Sensory evaluation. All the bread samples were evaluated by the trained panel of twenty five judges from the Institute of Food Science \& Nutrition, University of Sargodha, Pakistan for various attributes like colour, flavour, taste, texture and overall acceptability at $0,1^{\text {st }}$, and $2^{\text {nd }}$ days according to the method described by Meilgaard and Civile (2007).

Statistics. Results were statistically analysed by using ANOVA. Level of significance within mean was calculated by using complete randomized design Test and two factorial tests (Steel et al., 1997).

\section{Results and Discussion}

Proximate composition of straight grade flour. Proximate composition of straight grade wheat flour has been given in Table 2. The straight grade wheat flour contained moisture content $11.88 \%$, crude protein $11.32 \%$, crude fat $1.5 \%$, crude fibre $0.33 \%$, ash content $0.46 \%$ and NFE $74.51 \%$. The obtained results are closely related with the findings of Ayaz (1998).

Proximate composition of emulsifiers and hydrocolloids blended flour. Effect of emulsifiers and hydrocolloids on proximate composition of straight grade white flour have been depicted in Table 2 . The results showed that the addition of different levels of CMC, DATEM, MDG and guar gum to white flour have non-significant effect on ash, crude fat and crude protein while significant effect on moisture and nitrogen free extracts and highly significant effect on fibre in different treatments of treated flours. The highest significant value for crude fibre $1.25 \%$ was observed in $\mathrm{T}_{4}$ and $\mathrm{T}_{2}$ and lowest $0.33 \%$
Table 1. Treatments of flour having gums and emulsifiers prepared during study

\begin{tabular}{lllll}
\hline \hline $\begin{array}{l}\text { Treat- } \\
\text { ments }\end{array}$ & DATEM & G G & MDG & CMC \\
\cline { 2 - 5 } & \multicolumn{4}{c}{$(\%)$} \\
$\mathrm{T}_{0}$ & 0 & 0 & 0 & 0 \\
$\mathrm{~T}_{1}$ & 0.3 & 0.5 & 0 & 0 \\
$\mathrm{~T}_{2}$ & 0.6 & 1 & 0 & 0 \\
$\mathrm{~T}_{3}$ & 0 & 0 & 0.3 & 0.5 \\
$\mathrm{~T}_{4}$ & 0 & 0 & 0.6 & 1 \\
\hline \hline
\end{tabular}

Table 2. Proximate composition of emulsifiers-hydrocolloids blended flours and straight grade flour

\begin{tabular}{lllllll}
\hline \hline \multirow{2}{*}{$\begin{array}{l}\text { Treatments/ } \\
\text { flour }\end{array}$} & \multicolumn{2}{c}{ Moisture Protein } & Fat & Fibre & Ash & NFE \\
\cline { 2 - 7 } & \multicolumn{5}{c}{$(\%)$} \\
\hline $\mathrm{SGF}$ & $11.88^{\mathrm{b}}$ & $11.32^{\mathrm{c}}$ & $1.50^{\mathrm{d}}$ & $0.33^{\mathrm{f}}$ & $0.46^{\mathrm{e}}$ & $74.51^{\mathrm{a}}$ \\
$\mathrm{T}_{0}$ & $11.36^{\mathrm{c}}$ & $11.36^{\mathrm{a}}$ & $1.47^{\mathrm{a}}$ & $0.36^{\mathrm{d}}$ & $0.40^{\mathrm{c}}$ & $75.05^{\mathrm{a}}$ \\
$\mathrm{T}_{1}$ & $12.20^{\mathrm{d}}$ & $11.03^{\mathrm{b}}$ & $1.46^{\mathrm{a}}$ & $1.03^{\mathrm{b}}$ & $0.42^{\mathrm{b}}$ & $73.86^{\mathrm{c}}$ \\
$\mathrm{T}_{2}$ & $12.68^{\mathrm{a}}$ & $10.73^{\mathrm{b}}$ & $1.37^{\mathrm{b}}$ & $1.25^{\mathrm{a}}$ & $0.47^{\mathrm{a}}$ & $73.50^{\mathrm{d}}$ \\
$\mathrm{T}_{3}$ & $12.12^{\mathrm{d}}$ & $11.06^{\mathrm{c}}$ & $1.37^{\mathrm{b}}$ & $0.87^{\mathrm{c}}$ & $0.47^{\mathrm{a}}$ & $74.11^{\mathrm{b}}$ \\
$\mathrm{T}_{4}$ & $12.53^{\mathrm{b}}$ & $10.27^{\mathrm{d}}$ & $1.20^{\mathrm{c}}$ & $1.26^{\mathrm{a}}$ & $0.43^{\mathrm{b}}$ & $74.07^{\mathrm{b}}$ \\
\end{tabular}

DATEM = diacetylated tartaric acid esters of monoglycerides; $\mathrm{MDG}=$ di mono-glycerides; $\mathrm{GG}=$ guar-gum; $\mathrm{CMC}=$ Carboxymethylcellulose; $\mathrm{SGF}=$ straight grade flour; $\mathrm{T}_{0}=100 \%$ white flour; $\mathrm{T}_{1}=0.3 \%$ DATEM $+0.5 \%$ guar gum $+99.2 \%$ white flour; $\mathrm{T}_{2}=0.6 \%$ DATEM $+1.0 \%$ guar gum $+98.4 \%$ white flour; $\mathrm{T}_{3}=0.3 \% \mathrm{MDG}+0.5 \% \mathrm{CMC}+99.2 \%$ white flour; $\mathrm{T}_{4}=0.6 \%$ $\mathrm{MDG}+1.0 \% \mathrm{CMC}+98.4 \%$ white flour.

in $T_{0}$ of white flour. It shows that fibre contents increased by increasing the concentration of additives. These results reveal an increasing trend in moisture content with the increase in additives. Maximum value for moisture content has been found in $\mathrm{T}_{2}(12.69 \%)$ while minimum value in $\mathrm{T}_{0}$ as $11.387 \%$. $\mathrm{T}_{0}(11.367 \%)$ showed the maximum value while $\mathrm{T}_{4}(10.26 \%)$ showed minimum value for protein content of treatments. Means for nitrogen free extract (NFE) showed ( $2 \%$ ) that $\mathrm{T}_{0}$ contained highest value $(75.016 \%)$ for NFE followed by $\mathrm{T}_{3}(74.11 \%), \mathrm{T}_{4}(74.07 \%), \mathrm{T}_{1}(73.86 \%)$ while minimum value $(73.56 \%)$ was observed in $\mathrm{T}_{2}$. The overall range varied from $73.86-75.06 \%$. Results of present study are in-line with the findings reported by Rodge et al. (2012); Guarda et al. (2004) and Rehman and Ahmad (2003).

Rheological properties of emulsifiers and hydrocolloids blended flours. Effect of emulsifiers and hydrocolloids on the rheological properties of straight grade flour have been depicted in Table 3. It is obvious from 
Table 3 that water absorption capacity ranged from 60.87 to $62.93 \%$ in different treatments. The maximum water absorption was observed in $\mathrm{T}_{4}(62.93 \%)$ followed by $\mathrm{T}_{3}(62.53 \%), \mathrm{T}_{2}(61.83 \%)$ and $\mathrm{T}_{1}(61.33 \%)$ while the minimum water absorption capacity was observed in $\mathrm{T}_{0}(60.87 \%)$. Results showed that water absorption increased as the quantity of additives increased and changed by changing the emulsifiers and hydrocolloids as well. Results of present study are also in-line with the findings of Basak and Ercan (2011) and Sim et al. (2009). $\mathrm{T}_{4}$ contained highest value $(4.80 \mathrm{~min}$ ) for dough development followed by $\mathrm{T}_{3}(4.33 \mathrm{~min}), \mathrm{T}_{2}(4.30 \mathrm{~min})$ and $\mathrm{T}_{1}(4.10 \mathrm{~min})$ while minimum value $(3.90 \mathrm{~min})$ was observed in $\mathrm{T}_{0}$. The results showed an increasing trend in dough stability when used the combination of guar gum and DATEM while dough stability time decreased when combination of CMC and MDG emulsifier was used. The results of present study are in accordance with the findings of Shiyong and Yang (2013) and Sim et al. (2009).

Amylograph study of emulsifiers and hydrocolloids blended flours. Results showed that peak viscosity derived from amylogram varied highly significantly among different treatments. The mean values of peak viscosity ranged from 818.33 to $950.00 \mathrm{BU}$ among various treatments (Table 3 ). The highest peak viscosity i.e. $950.00 \mathrm{BU}$ was recorded in $\mathrm{T}_{2}$, followed by $\mathrm{T}_{1}$ (908.33 BU), $\mathrm{T}_{0}(860 \mathrm{BU})$ and $\mathrm{T}_{3}(858.33 \mathrm{BU})$ while minimum value $(818 \mathrm{BU})$ was observed in $\mathrm{T}_{4}$. In the present study, differences in the peaks of different treated flour treatments were due to differences in the $\alpha$-amylase activity. The results of present study are comparable with the findings of Ashwini et al. (2009) and Sim et al. (2009) who reported similar increasing and decreasing trend of peak viscosity within different treatments of treated flours as the quantity of additives increased in the blends.

Sensory evaluation of emulsifiers-hydrocolloids blended breads. Emulsifiers-hydrocolloids blended breads were prepared and analyzed for sensory attributes like loaf volume, colour of crust, symmetry of form, evenness of bake, break and shred, crust character, grain, crumb colour, aroma, mastication, taste and texture to find out suitable composition of bread showing consumer acceptability. The data about mean scores of different treatments on various parameters has been presented in Table 4 . The results showed that, symmetry of form, evenness of bake, break and shred, crust character, grain, crumb colour, mastication, taste were non significantly effected while loaf volume, colour of crust,
Table 3. Ferinographic and amylographic study of emulsifiers-hydrocolloids blended flours

\begin{tabular}{lllll}
\hline \hline $\begin{array}{l}\text { Treat- } \\
\text { ments }\end{array}$ & $\begin{array}{l}\text { Water } \\
\text { absorption } \\
(\%)\end{array}$ & $\begin{array}{l}\text { Dough } \\
\text { development } \\
\text { DDT (min) }\end{array}$ & $\begin{array}{l}\text { Dough } \\
\text { stability } \\
(\mathrm{min})\end{array}$ & $\begin{array}{l}\text { Viscosity } \\
(\mathrm{BU})\end{array}$ \\
\hline $\mathrm{T}_{0}$ & $60.87^{\mathrm{e}}$ & $3.90^{\mathrm{d}}$ & $7.80^{\mathrm{c}}$ & $860.00^{\mathrm{c}}$ \\
$\mathrm{T}_{1}$ & $61.33^{\mathrm{d}}$ & $4.10^{\mathrm{b}}$ & $9.00^{\mathrm{b}}$ & $908.33^{\mathrm{b}}$ \\
$\mathrm{T}_{2}$ & $61.83^{\mathrm{c}}$ & $4.30^{\mathrm{c}}$ & $9.10^{\mathrm{a}}$ & $950.00^{\mathrm{a}}$ \\
$\mathrm{T}_{3}$ & $62.53^{\mathrm{b}}$ & $4.33^{\mathrm{c}}$ & $7.30^{\mathrm{d}}$ & $858.33^{\mathrm{d}}$ \\
$\mathrm{T}_{4}$ & $62.93^{\mathrm{a}}$ & $4.80^{\mathrm{a}}$ & $7.00^{\mathrm{e}}$ & $818.33^{\mathrm{e}}$ \\
\hline \hline
\end{tabular}

Table 4. Sensory attributes of emulsifiers-hydrocolloids blended bread

\begin{tabular}{llllll}
\hline \hline Treatments & $\mathrm{T}_{0}$ & $\mathrm{~T}_{1}$ & $\mathrm{~T}_{2}$ & $\mathrm{~T}_{3}$ & $\mathrm{~T}_{4}$ \\
\cline { 2 - 6 } & \multicolumn{5}{c}{ External characteristics } \\
\hline Loaf volume & $6.17^{\mathrm{d}}$ & $8.28^{\mathrm{ab}}$ & $8.72^{\mathrm{a}}$ & $7.56^{\mathrm{a}}$ & $6.33^{\mathrm{bc}}$ \\
Colour of crust & $6.67^{\mathrm{b}}$ & $5.67^{\mathrm{d}}$ & $5.89^{\mathrm{cd}}$ & $7.56^{\mathrm{a}}$ & $6.33^{\mathrm{bc}}$ \\
Symmetry of form & $2.56^{\mathrm{a}}$ & $2.50^{\mathrm{b}}$ & $2.22^{\mathrm{d}}$ & $2.44^{\mathrm{c}}$ & $2.50^{\mathrm{b}}$ \\
Evenness of bake & $2.56^{\mathrm{b}}$ & $2.11^{\mathrm{d}}$ & $2.39^{\mathrm{c}}$ & $2.72^{\mathrm{a}}$ & $2.39^{\mathrm{c}}$ \\
Crust character & $2.44^{\mathrm{a}}$ & $2.33^{\mathrm{c}}$ & $2.44^{\mathrm{a}}$ & $2.28^{\mathrm{d}}$ & $2.39^{\mathrm{b}}$ \\
Break and shred & $2.39^{\mathrm{b}}$ & $2.44^{\mathrm{a}}$ & $2.33^{\mathrm{c}}$ & $2.39^{\mathrm{b}}$ & $2.44^{\mathrm{a}}$ \\
& & & & & \\
Grain & $8.22^{\mathrm{b}}$ & $8.22^{\mathrm{b}}$ & $8.33^{\mathrm{a}}$ & $8.00^{\mathrm{d}}$ & $8.17^{\mathrm{c}}$ \\
Colour of crumb & $8.44^{\mathrm{b}}$ & $8.28^{\mathrm{d}}$ & $8.33^{\mathrm{c}}$ & $8.67^{\mathrm{a}}$ & $8.33^{\mathrm{c}}$ \\
Aroma & $6.67^{\mathrm{c}}$ & $7.78^{\mathrm{ab}}$ & $8.11^{\mathrm{ab}}$ & $8.44^{\mathrm{a}}$ & $7.67^{\mathrm{b}}$ \\
Mastication & $8.00^{\mathrm{c}}$ & $7.78^{\mathrm{d}}$ & $8.22^{\mathrm{b}}$ & $8.00^{\mathrm{c}}$ & $8.44^{\mathrm{a}}$ \\
Taste & $12.33^{\mathrm{c}}$ & $13.33^{\mathrm{b}}$ & $13.67^{\mathrm{ab}}$ & $14.00^{\mathrm{ab}}$ & $14.33^{\mathrm{a}}$ \\
Texture & $11.22^{\mathrm{d}}$ & $12.22^{\mathrm{c}}$ & $12.56^{\mathrm{bc}}$ & $12.89^{\mathrm{ab}}$ & $13.22^{\mathrm{a}}$ \\
\hline \hline
\end{tabular}

$\mathrm{T}_{0}=100 \%$ white flour; $\mathrm{T}_{1}=0.3 \%$ DATEM $+0.5 \%$ guar gum $+99.2 \%$ white flour; $\mathrm{T}_{2}=0.6 \%$ DATEM $+1.0 \%$ guar gum $+98.4 \%$ white flour; $\mathrm{T}_{3}=0.3 \% \mathrm{MDG}+0.5 \% \mathrm{CMC}+99.2 \%$ white flour; $\mathrm{T}_{4}=0.6 \% \mathrm{MDG}+1.0 \% \mathrm{CMC}+98.4 \%$ white flour.

texture and aroma were significantly affected by the addition of these additives. These results are in line with the observations of earlier researchers (Regine et al., 2013; Mohammad et al., 2012; Rodge et al., 2012; Sara et al., 2012; Carr et al., 2006; Shahzadi et al., 2005; Guarda et al., 2004; Qarooni, 2005; 1996).

\section{Conclusion}

It is concluded from the present investigation that gums and emulsifiers have significant affect on water absorption, dough development time and dough stability. Overall acceptability like colour, volume, taste, aroma, crust colour, crumb texture etc. could be highly improved with the help of gums and emulsifiers according to the 
climatic conditions of the specific area with respect to wheat quality. The results acquired from the present study may be very valuable for industries to decide to take best additives/improver for their quality products.

\section{References}

AACC. 2000. Approved Methods of American Association of Cereal Chemists, Method 4415A, $10^{\text {th }}$ edition. The American Association of Cereal Chemists, Inc., St. Paul, Minnesota, USA.

Ashwini, A., Jyotsna, R., Indrani, D. 2009. Effect of hydrocolloids and emulsifiers on the rheological, microstructural and quality characteristics of eggless cake. Food Hydrocolloids, 23: 700-707.

Ayaz, M.S. 1998. Strengthening of Commercial Wheat Flour for the Suitablility of Pizza Production in Pakistan. M.SC. (Hons) Thesis, Department of Food Technology, University of Agriculture, Faisalabad, Pakistan.

Azizi, M.H., Rao, G.V. 2005. Effect of storage of surfactant gels on the bread making quality of wheat flour. Food Chemistry, 89: 133-138.

Bakke, A., Vickers, Z. 2007. Consumer liking of refined and whole wheat breads. Journal of Food Science, 72: S473-S480.

Basak, S., Ercan, R. 2011. Effects of some hydrocolloids and surfactant on the rheological properties of hard wheat flour dough by using response surface methodology. The Journal of Food, 36: 77-82.

Carr, L.G., Rodas, M.A.B., Della Torre, J.C.B., Tadini, C.C. 2006. Physical, textural and sensory characteristics of 7-day frozen part-baked French bread. LWT - Food Science and Technology, 39: 540-547.

Cauvain, S.P. 1994. New mixer for variety bread production. The Europe Food Drink Review, 4: 51- 53.

Gómez-Diaz, D., Navaza, J.M. 2003. Comments about rheological effects of food. Journal of Food Agriculture and Environment, 1: 98-102.

Guarda, A., Rosell, C.M., Benedito, C., Galotto, M.J. 2004. Different hydrocolloids as bread improvers and anti staling agents. Food Hydrocolloid, 18: 241-247.

Lorena, S.S., Ribotta, P.D., Leon, A.E., Pérez, G.T. 2008. Influence of gluten-free flours and their mixtures on beatter properties and bread quality. Food Bioprocess Technology, 3: 577-585.

Meilgaard, M.C., Civile, G.V., Carr, B.T. 2007. Sensory
Evaluation Techniques, $4^{\text {th }}$ edition, C.R.C. Press, New York, USA.

Mohammed, I., Ahmed, A.R., Senge, B. 2012. Dough rheology and bread quality of wheat-chickpea flour blends. Industrial Crops and Products, 36: 196-202.

Qarooni, J. 1996. Flat Bread Technology, 206 pp., Springer, Heidelberg: http://dx.doi.org/10.1007/9781-4613-1175-1

Regine, S., Szatmari, M., Bagdi, A., Tömösközi, S. 2013. Optimisation of bread quality produced from wheat and proso millet (Panicum miliaceum L.) by adding emulsifiers, transglutaminase and xylanase. Food Science and Technology, 51: 361-366.

Rehman, S.U., Ahmad, M. 2003. Effect of carboxy methyle cellulose and carrajeenan gum on the shelf life of bread. Pakistan Journal of Food Science, 13: 49-52.

Rodge, A.B., Sonkamble, M.S., Salve, V.R., Hashmi, I.S. 2012. Effect of hydrocolloid (guar gum) incorporation on the quality characteristics of bread. Food Processing and Technology, 3: 1-17.

Sara, R., Movahhed, S., Nematti, N., Sokotifar, R. 2012. Evaluation of the effect of carboxy methyl cellulose on sensory properties of gluten-free cake. Research Journal of Applied Sciences, Engineering and Technology, 4: 3819-3821.

Selomulyo, V. O., Zhou, W. 2007. Frozen bread dough: effects of freezing storage and dough improvers. Journal of Cereal Science, 45: 1-17.

Shahzadi, N., Butt, M., Rehman, S., Sharif, K. 2005. Chemical characteristics of various treated flours. International Journal of Agriculture and Biology, 7: 105-108.

Shiyong, D., Yang, J. 2003. The influence of emulsifiers on the rheological properties of wheat flour dough and quality of fried instant noodles. LWT - Food Science and Technology, 53: 61-69.

Sim, S.Y., Cheng, L.H., Noor Aziah, A.A. 2009. Effects of selected food gums on wheat flour or dough properties. Asian Journal of Food and Agro-industry, 2: 937-947.

Stampfli, L., Nersten, B. 1995. Emulsifiers in bread making. Food Chemistry, 52: 353-360.

Steel, R.G.D., Torrie, J.H., Dickey, D.A. 1997. Principles and Procedures of Statistics - A Biometrical Approach, $3^{\text {rd }}$ edition, McGraw Hill Book Co. Inc., New York, USA. 